\title{
Exchange Market Pressure in China: A Re-Examination Based on Girton-Roper Monetary Model
}

\author{
Xiangsheng Dou \\ School of Economics and Management, Southwest Jiaotong University, Chengdu, China \\ Email: douxiangsheng@tsinghua.org.cn
}

How to cite this paper: Dou, X.S. (2017) Exchange Market Pressure in China: A ReExamination Based on Girton-Roper Monetary Model. Theoretical Economics Letters, 7, 1306-1317.

https://doi.org/10.4236/tel.2017.75089

Received: July 2, 2017

Accepted: July 30, 2017

Published: August 2, 2017

Copyright $\odot 2017$ by author and Scientific Research Publishing Inc. This work is licensed under the Creative Commons Attribution International License (CC BY 4.0). http://creativecommons.org/licenses/by/4.0/

\begin{abstract}
For China's inefficient foreign exchange market, as the foreign exchange market is difficult to clear in time, so the foreign exchange market pressure always exists. Therefore, the in-depth study and discussion of China's foreign exchange market pressure issue has important practical significance. This paper applies Lance Girton and Don Roper's monetary model of exchange market pressure to China's experience. The purpose of this paper is mainly to test whether the excess supply of money in China can be absorbed by some combination of the change in exchange rate and the change in foreign reserves. The results of empirical analysis indicate that the basic theoretical proposition is accordant with the practice.
\end{abstract}

\section{Keywords}

Exchange Market Pressure, Exchange Rate, Foreign Exchange Reserves

\section{Introduction}

Exchange rate and foreign exchange play a very important role in economic operation and development for a country. Since the reform and opening up, China's exchange rate and foreign exchange management system has undergone a continuous reform process, and has initially realized the operation and management of marketization. However, because China's market economy system is not perfect, there are many imperfections in China's exchange rate and foreign exchange system. This led to the long-term pressure of China's foreign exchange market, and sometimes it even requires the strong regulation of the government to gradually release the pressure. Therefore, the study and discussion on the problem of China's foreign exchange market pressure have important practical significance. 
The monetary approach to the balance of payments has received considerable attention. However, most of the empirical studies are based on a small country with fixed exchange rates [1] [2]. Therefore, its application is greatly restricted. To solve this problem, Lance Girton and Don Roper (1977) designed the monetary model of exchange market pressure. The so-called "exchange market pressure", according to Lance Girton and Don Roper's definition [3], is the pressure on foreign exchange reserves and exchange rate when there exists an excess of domestic money supply over money demand in a managed floating exchange rate regime. The basic theoretical proposition is that any such excess supply of money can be relieved by foreign exchange depreciation, a loss in foreign reserves, or, in the context of a managed float, by some combination of them [4].

Lance Girton and Don Roper's monetary model of exchange market pressure was specifically designed for the Canadian managed float during the period 1952-62 [5]. In the analysis for the Canadian, Lance Girton and Don Roper used two country factors concerned of Canadian and the U.S. to test the model. Based on the G-R model, the Connolly and Silveira (1979) made a simplified G-R model only considering a tested country factor concerned for Brazil monetary experience during the period 1955-75. Modeste (1981) and Kim (1985) applied same simplified model to Argentina experience in the 1970s and Korea experience for the period from March 1980 to July 1983, respectively [6] [7]. All their empirical analysis made expected results.

As compared with the Argentina's and the Korea's, the foreign exchange market scales of China are comparatively greater and steadier. Especially, since January 1994, the Renminbi exchange rate has made a frequent and continuous change despite being strictly limited in a narrow band. Meanwhile, China's foreign reserves have been quickly increasing, so the greater exchange market pressure mainly comes from the changes in foreign reserves to a great extent. Obviously, China's experience provides another good opportunity for testing the monetary model of exchange market pressure.

We used the data for 1994-2008 to test China's foreign exchange market pressure. The results show that China's foreign exchange market pressure is mainly absorbed by foreign exchange reserves, but the role of exchange rate does not seem to be significant. This can be due to the beginning of the formal implementation of a single market exchange rate system from 1994, so China's foreign exchange market was still in an unstable state. In particular, the country made relatively strict management on foreign exchange market, and the amplitude of exchange rate fluctuation was limited to a small scope. Therefore, the test results of using so period data may not be accurate. In recent years, as China has allowed greater exchange rate fluctuations, so at least in theory, the role of exchange rate in the adjustment of foreign exchange market pressure will be more and more significant. This paper attempts to use the latest data to re-examine the pressure of China's foreign exchange market to provide theoretical basis for policy practice.

The remainder of this paper is as follows. Section II explains exchange rate 
and foreign exchange system reform in China. Section III sets a simple monetary model of exchange market pressure. In Section IV, empirical results generated from estimating the EMP equation are reported. Section $V$ discusses the further reform of China's exchange rate and foreign exchange system. Finally, this paper summarizes the main conclusions of the paper.

\section{Exchange Rate and Foreign Exchange System Reform in China}

China's exchange rate and foreign exchange management system has experienced the reform and transformation from planned management to marketoriented management. Before 1980, China had been practiced official exchange rate system in a long period of time, which was strictly controlled by the state. The basic characteristic of this exchange rate and foreign exchange management system is that the state exercises strict control over foreign exchange, and all foreign exchange earnings have to be submitted to the state. And the plan of demand for foreign exchange is required to be submitted to foreign exchange management department in advance. Only after the plan is examined and approved, the corresponding foreign exchange quota can be obtained for import payment. The exchange rate is entirely determined by the state, while the state often makes necessary adjustments in accordance with economic situation. Because of the needs for the country's imports, the RMB currency has been highly overvalued in this period.

China had been practiced a double exchange rate system from 1981 to 1993 to transit from the planned system to the market system. The characteristic of this exchange rate system is the co-exist of the official exchange rate and the trade settlement exchange rate (market exchange rate) used for import and export trade settlement and the economic performance accounting of foreign trade firms. At the same time, the state deliberately lowered the official exchange rate to gradually move closer to the trade settlement exchange rate. In addition, the state implemented the new system of foreign exchange settlement and sale, and abandoned old strict foreign exchange approval system. For example, the establishment of special foreign exchange management agency (the national bureau of foreign exchange administration), the establishment of foreign exchange retention system for firm, the establishment of foreign exchange swap markets, the implementation of individual foreign exchange rate retention system, the establishment of foreign exchange business system and the coexistence of a variety of financial institutions dominated by Chinese central banks, and so forth.

New national provisions have made that, domestic banks could open domestic foreign currency deposit business, personal foreign exchange could be deposited in the bank, and the withdrawal of foreign exchange within the prescribed amount and purpose was allowed for overseas use since 1985. Some developed areas of economy and overseas Chinese have opened up personal foreign exchange business to allow the purchase and sale of personal foreign exchange according to market swap price since 1988 . 
In fact, China's exchange rate and foreign exchange management has been in transition from the planned economic system to the market economy system to lay the foundation for the final implementation of a single exchange rate and foreign exchange system since 1981 . However, China's exchange rate and foreign exchange management system still belongs to the administrative system, while the role of market mechanism is still very limited in this period.

China has abolished the double exchange rate system and implemented a single managed floating exchange rate system based on foreign exchange market since 1994. At first, foreign exchange settlement system was practiced and the proportional retention system of foreign exchange was cancelled, while the bank sale of foreign exchange system and conditional convertibility for the RMB was carried out and a unified national inter-bank foreign exchange trading market was established. Since then, China has completely eliminated the trading restrictions for foreign exchange to achieve full convertibility under current accounts. At this point, the official exchange rate and the market exchange rate of RMB are fully unified [8].

At present, although both the formation and regulation of RMB exchange rate and foreign exchange management have basically realized the marketization, the market-oriented management level of exchange rate and foreign exchange is still low compared with the developed countries. Especially, there is still the administration-oriented hard management in a certain degree. Therefore, the domestic foreign exchange market is still in development and improvement, while the excessive management but insufficient floating of RMB exchange rate is obvious. Therefore, China's exchange rate and foreign exchange management system needs further be reformed and improved.

\section{Methodology and Model}

The formal monetary model is set around the notion of money demand and money supply, and based on two basic conditions of the equilibrium condition for the monetary sector and the imposition of purchasing power parity. The model can be expressed with the following equations:

$$
\begin{gathered}
M=R+D \\
L=k P Y \\
P=E P^{*} \\
L=M
\end{gathered}
$$

where $M$ in Equation (1) is nominal money supply defined as the sum of net foreign assets, $R$, and domestic credit, D. $L$ in Equation (2) is demand for money taking a simple form of the Cambridge cash balance, where $k$ is the fraction of people hold in the form of money balances, and $P$ and $Y$ stand for the domestic price level and real income, respectively. Equation (3) is the condition of purchasing power parity, where $E$ and $P^{*}$ stand for the nominal exchange rate and the foreign price level, respectively. Equation (4) is the condition of the equilibrium for the monetary sector. 
Substituting (3) into (2), and (1) and (2) into (4), differentiating logarithmically, and expressing the result in terms of percentage changes, the following empirical equation corresponding to G-R's exchange market pressure is obtained:

$$
r+e=-d+p^{*}+y
$$

where $r$ is the change in foreign reserves as a proportion of the money supply, $e$ is the percentage appreciation of the exchange rate, $d$ is the change in domestic credit as a proportion of the money supply, $p^{*}$ is the percentage appreciation of the foreign price level, and $y$ is the percentage appreciation of real income.

Equation (5) states that if the growth rate of world prices and permanent income is given, any change in the growth rate of domestic credit can be absorbed by the change in foreign reserves, or the change in exchange rates, or some combination of them.

\section{Empirical Results}

The empirical analysis is carried out with quarterly data over the period 2010:1 to 2017:1. The definition of money used here is the broad definition M2 that is the sum of domestic credit for $D$ and net foreign assets for $R$ of the consolidated banking system in China. The U.S. producer price index was used for the foreign price, $P^{*}$. Gross domestic products adjusted by the China consumer price index used for real income, $Y$. The quarterly average nominal exchange rates of RMB Yuan to U.S. Dollar used for the exchange rates, $E$. The data of $P^{*}$ come from the United States Department of Labor (https://www.bls.gov/home.htm, 2017-0523), and other data come from the People's Bank of China (http://www.pbc.gov.cn, 2017-05-23). All the variables are expressed in logarithms.

First of all, paper uses the combination of $r$ and $e$ as dependent variable to test the EMP model. ADF unit tests suggest that $r+e, d, p^{*}$ and $y$ is respectively integrated of order 1 (see Table 1), and the Johansen cointegration test further shows that $r+e$ is cointegrated with $d, p^{*}$ and $y$ (see Series 1 in Table 2) [9]. Therefore, the cointegrated system with the OLS method may be formulated. The results of regression, reported in regression Equation (1) in Table 3, cannot provide good evidence to support the exchange market pressure model. Although all the estimated coefficients correspond to their hypothesized theoretical values of minus unity for $d$, and plus unity for $p^{*}$ and $y$ and the $F$-statistic value of 121.20 implies that the three variables are jointly useful in explaining the dependent variable $(r+e)$, the $t$ value of the variable $\mathrm{p}^{*}$ is statistically insignificant. This indicates that the Equation (1) is not fair.

Another test of the exchange market pressure model is to view whether or not the measure $r+e$ is sensitive to its composition between exchange rate and reserve change. To do this, another independent variable, $Q=e / r$, is added the right-hand side of equation (5) in regressions. Lance Girton and Don Roper (1977) used the simple ratio $e / r$ for $Q$, but Connolly and Silveira (1979), Modeste (1981), and Kim (1985) used the ratio $(e-1) /(r-1)$ for $Q$. This paper uses the 
Table 1. ADF unit root tests.

\begin{tabular}{|c|c|c|c|}
\hline Variables & Test type & Statistic value & Critical value \\
\hline$r+e$ & $(c, \mathrm{t}, 2)$ & -2.9433 & $-3.2367^{\star}$ \\
\hline$\Delta(r+e)$ & $(c, \mathrm{t}, 2)$ & -4.1685 & $-3.6118^{\star *}$ \\
\hline$r$ & $(c, t, 1)$ & -1.9934 & $-3.2279^{*}$ \\
\hline$\Delta \mathrm{r}$ & $(c, 0,1)$ & -2.6694 & $-2.6290^{*}$ \\
\hline$e$ & $(c, 0,1)$ & -1.8109 & $-2.6290^{*}$ \\
\hline$\Delta \mathrm{e}$ & $(c, 0,1)$ & -5.1010 & $-3.7204^{\star \star \star}$ \\
\hline$d$ & $(c, \mathrm{t}, 1)$ & -1.9934 & $-3.2279^{\star}$ \\
\hline$\Delta \mathrm{d}$ & $(c, 0,1)$ & -2.6694 & $-2.6290^{*}$ \\
\hline$P^{*}$ & $(c, t, 5)$ & -2.6060 & $-3.2535^{\star}$ \\
\hline$\Delta p^{*}$ & $(c, t, 1)$ & -7.0904 & $-4.3738^{* * *}$ \\
\hline y & $(c, t, 3)$ & -1.9330 & $-3.2418^{\star}$ \\
\hline$\Delta y$ & $(c, t, 1)$ & -4.5701 & $-4.3738^{\star * \star}$ \\
\hline$Q$ & $(c, 0,1)$ & -1.6007 & $-2.6290^{*}$ \\
\hline$\Delta Q$ & $(c, 0,1)$ & -5.2685 & $-3.7204^{* * *}$ \\
\hline
\end{tabular}

Note: ${ }^{*},{ }^{*}$ and ${ }^{* * *}$ indicate the critical values at the $10 \%, 5 \%$ and $1 \%$ level, respectively. In $(c, t, 1)$ of test type, $c$ and $t$ stand for Intercept and Trend respectively, and $l$ stands for the Lagged differences. $\Delta$ stands for the first order difference.

Table 2. Johansen co-integration tests.

\begin{tabular}{|c|c|c|c|c|c|}
\hline Series & $\begin{array}{l}\text { Hypothesized } \\
\text { No. of CE(s) }\end{array}$ & Eigenvalue & $\begin{array}{c}\text { Trace } \\
\text { Statistic }\end{array}$ & $\begin{array}{c}5 \% \\
\text { Critical Value }\end{array}$ & $\begin{array}{c}1 \% \\
\text { Critical Value }\end{array}$ \\
\hline \multirow{4}{*}{1} & $\rho=0^{*}$ & 0.5674 & 51.9453 & 47.21 & 54.46 \\
\hline & $\rho \leq 1^{*}$ & 0.5118 & 30.1588 & 29.68 & 36.65 \\
\hline & $\rho \leq 2^{*}$ & 0.3498 & 11.5158 & 15.41 & 20.04 \\
\hline & $\rho \leq 3$ & 0.0124 & 0.3234 & 3.76 & 6.65 \\
\hline \multirow{5}{*}{2} & $\rho=0^{*}$ & 0.9668 & 138.7460 & 68.52 & 76.07 \\
\hline & $\rho \leq 1^{*}$ & 0.5799 & 50.2049 & 47.21 & 54.46 \\
\hline & $\rho \leq 2^{*}$ & 0.5024 & 27.6548 & 29.68 & 35.65 \\
\hline & $\rho \leq 3$ & 0.2856 & 9.5075 & 15.40 & 20.04 \\
\hline & $\rho \leq 4$ & 0.0289 & 0.7617 & 3.76 & 6.65 \\
\hline \multirow[t]{2}{*}{3} & - & - & - & - & - \\
\hline & $\rho=0^{* *}$ & 0.7662 & 78.0167 & 47.21 & 54.46 \\
\hline \multirow{3}{*}{4} & $\rho \leq 1^{\star *}$ & 0.5478 & 40.2273 & 29.68 & 35.65 \\
\hline & $\rho \leq 2^{*}$ & 0.5223 & 19.5911 & 15.41 & 20.04 \\
\hline & $\rho \leq 3$ & 0.0146 & 0.3821 & 3.76 & 6.65 \\
\hline
\end{tabular}

Note: ${ }^{*}$ and ${ }^{* *}$ denotes rejection of the hypothesis at the 0.05 and 0.01 level, respectively. 
Table 3. The estimated results.

\begin{tabular}{|c|c|c|c|c|c|c|c|c|c|}
\hline $\begin{array}{c}\text { Regression } \\
\text { Equation }\end{array}$ & $\begin{array}{l}\text { Dependent } \\
\text { Variable }\end{array}$ & Const. & $d$ & $p^{*}$ & $y$ & $Q$ & $R^{2}$ & $\begin{array}{c}F \\
D . W .\end{array}$ & $\begin{array}{l}S E R \\
S S R\end{array}$ \\
\hline 1 & $r+e$ & $\begin{array}{c}0.734152 \\
\left(10.19^{* * *}\right)\end{array}$ & $\begin{array}{c}-0.674763 \\
\left(8.11^{* * *}\right)\end{array}$ & $\begin{array}{c}2.088932 \\
(1.44)\end{array}$ & $\begin{array}{c}0.254478 \\
\left(2.19^{* *}\right)\end{array}$ & - & $\begin{array}{c}0.94 \\
-\end{array}$ & $\begin{array}{c}121.20 \\
2.78\end{array}$ & $\begin{array}{l}0.0110 \\
0.0029\end{array}$ \\
\hline 2 & $r+e$ & $\begin{array}{c}0.884567 \\
\left(29.50^{\star * *}\right)\end{array}$ & $\begin{array}{l}-0.874002 \\
\left(26.70^{\star * *}\right)\end{array}$ & $\begin{array}{c}2.989536 \\
\left(3.51^{\star *}\right)\end{array}$ & $\begin{array}{c}0.106711 \\
\left(2.14^{\star}\right)\end{array}$ & $\begin{array}{c}0.171813 \\
\left(25.18^{\star * *}\right)\end{array}$ & $\begin{array}{c}0.99 \\
-\end{array}$ & $\begin{array}{c}2357.56 \\
2.07\end{array}$ & $\begin{array}{l}0.0022 \\
0.0001\end{array}$ \\
\hline 3 & $r$ & $\begin{array}{c}1 \\
\left(1.16 \mathrm{E}+14^{\star * *}\right)\end{array}$ & $\begin{array}{c}-1 \\
\left(9.13 \mathrm{E}+13^{\star \star \star}\right)\end{array}$ & $\begin{array}{c}-2.40 \mathrm{E}-13 \\
\left(2.04^{\star \star}\right)\end{array}$ & $\begin{array}{c}-7.92 \mathrm{E}-15 \\
(0.78)\end{array}$ & $\begin{array}{l}- \\
-\end{array}$ & $\begin{array}{l}1 \\
-\end{array}$ & $\begin{array}{c}3 \mathrm{E}+27 \\
0.36\end{array}$ & $\begin{array}{l}2.70 \mathrm{E}-15 \\
1.74 \mathrm{E}-28\end{array}$ \\
\hline 4 & $e$ & $\begin{array}{c}-0.153691 \\
\left(4.32^{\star * *}\right)\end{array}$ & $\begin{array}{l}0.200418 \\
\left(4.33^{* * *}\right)\end{array}$ & $\begin{array}{c}0.056883 \\
(0.55)\end{array}$ & $\begin{array}{c}0.022233 \\
(0.98)\end{array}$ & - & $\begin{array}{c}0.44 \\
-\end{array}$ & $\begin{array}{l}6.31 \\
2.66\end{array}$ & $\begin{array}{l}0.0118 \\
0.0033\end{array}$ \\
\hline
\end{tabular}

Note: All equations were run using the OLS technique. The numbers in parentheses below the estimated coefficients indicate $t$-values; ${ }^{*} * *$ and ${ }^{* * *}$ indicate the significant at the $10 \%, 5 \%$ and $1 \%$ level, respectively. $R^{2}=$ coefficient of determination; $F=F$-statistic; $D . W$. = Durbin-Watson statistic; SER= standard error of the regression; $S S R=$ sum of squared residuals; Other symbols are defined in the text.

simple ratio $e / r$ for $Q$. ADF unit tests suggest that $r+e, d, p^{*}, y$ and $Q$ is respectively integrated of order 1 (see Table 1), and the Johansen cointegration test further shows that $r+e$ is cointegrated with $d, p^{*}, y$ and $Q$ (see Series 2 in Table 2). Therefore, the cointegrated system with the OLS method may be formulated. The results are reported in regression Equation (2) in Table 3. The $t$ value of every variable indicates that all the estimated coefficients are statistically significant. $F$-statistic value of 2357.56 implies that the four variables are jointly useful in explaining the dependent variable $r+e$. The $R^{2}$ value of 0.99 , the D.W. value of 2.07, the $S E R$ value of 0.0022 and the $S S R$ value of 0.0001 suggest that the equation 2 has a very good explanatory power. Especially, statistically significant $\mathrm{t}$ value for the variable $Q$ indicates that the measure of exchange market pressure in China is sensitive to its composition. This finding is different from the reports of Girton and Roper (1977) for Canada, Connolly and Silveira (1979) for Brazil, and Kim (1985) for Korea in their models of the EMP.

For the reason of comparison, the further tests to be performed are to use the variable $r$ and the variable $e$ as sole dependent variable to test the EMP model respectively to see whether or not it is inferior to the combination of both. In the first instance, the variable $r$ is used as sole dependent variable. ADF unit tests suggest that $r, d, p^{*}$ and $y$ is integrated of order 1, respectively (see Table 1). However, because there is serious multicollinearity between $r, d, p^{*}$ and $y$, the Johansen cointegration test is invalid. Even if the econometric equation was established, the results are not good (see regression Equation (3) in Table 3). This finding implies that exchange market pressure in China is difficult to be completely absorbed through adjustments in foreign reserves.

The next test to be performed is to use the variable $e$ as sole dependent variable. ADF unit tests suggest that $e, d, p^{*}$, and $y$ are integrated of order 1 respectively (see Table 1), and the Johansen cointegration test further shows that $e$ is cointegrated with $d, p^{*}$ and $y$ (see Series 4 in Table 2). Therefore, the cointegrated system in the OLS method may be formulated. The results are reported in regression Equation (4) in Table 3. In regression Equation (4), besides that the 
variable $p^{*}$ and $y$ are statistically insignificant, the estimated coefficients of the variable $\mathrm{d}$ has a wrong sign. Furthermore, the $R^{2}$ value of 0.44 indicates that Equation (4) has poor explanatory power. Therefore, overall speaking, the results that $e$ is used as sole dependent variable are inferior to those that are obtained from the EMP equation.

\section{Discussion}

\subsection{Structural Change in Foreign Exchange Markets}

We have used the data from 1994 to 2010 to test, and concluded that using foreign exchange reserves and exchange rate sum $(r+e)$ as an explained variable were superior to one of them $(r$ or $e$ ). However, it $(r+e)$ is not sensitive to the ratio of exchange rates to foreign exchange reserves (e/r) (see Table 4). Another interesting thing is that, only using foreign exchange reserves $(r)$ as an explained variable has relatively good regression results with data from 1994 to 2010 (see Table 4). However, if using new data (2010: 1 to 2017: 1) to do regression has wrong symbols, and foreign price $\left(p^{*}\right)$ and domestic income (y) have statistically insignificant impact on foreign exchange reserves $(r)$ (see Table 3 ). This shows that China's foreign exchange market has undergone significant changes.

Although China has implemented a single managed floating exchange rate regime and deregulated foreign exchange since 1994, it is a gradual process of deregulation and China has strengthened its control over exchange rates and foreign exchange in the period of the East Asian financial crisis in 1998. Obviously, China has not really realized the market-oriented management of exchange rate and foreign exchange in the period 1994-2010. In addition to having a strong central government management tradition for China, it is more important that China's foreign exchange market has not really formed in this period. Therefore, the administrative exchange rate and foreign exchange system in this period are obvious, which led to the limited change in exchange rate (RMB appreciation) and increasing in foreign exchange reserves.

Table 4. Estimation results.

\begin{tabular}{|c|c|c|c|c|c|c|c|c|c|}
\hline $\begin{array}{l}\text { egression } \\
\text { Equation }\end{array}$ & $\begin{array}{c}\text { Dependent } \\
\text { Variable }\end{array}$ & Const. & $d$ & $p^{*}$ & $y$ & $Q$ & $R^{2}$ & $\begin{array}{c}F \\
D . W .\end{array}$ & $\begin{array}{l}S E R \\
S S R\end{array}$ \\
\hline 1 & $r+e$ & $\begin{array}{c}0.00716 \\
\left(1.89^{*}\right)\end{array}$ & $\begin{array}{c}-0.15441 \\
\left(1.77^{\star}\right)\end{array}$ & $\begin{array}{l}0.63331 \\
\left(3.39^{\star *}\right)\end{array}$ & $\begin{array}{c}0.14058 \\
\left(7.47^{\star * *}\right)\end{array}$ & - & $\begin{array}{c}0.6991 \\
-\end{array}$ & $\begin{array}{c}32.54 \\
2.41\end{array}$ & $\begin{array}{l}0.0024 \\
0.0003\end{array}$ \\
\hline 2 & $r+e$ & $\begin{array}{c}0.00713 \\
\left(1.84^{*}\right)\end{array}$ & $\begin{array}{c}-0.15798 \\
\left(1.78^{\star}\right)\end{array}$ & $\begin{array}{l}0.64666 \\
\left(3.42^{\star \star}\right)\end{array}$ & $\begin{array}{c}0.14275 \\
\left(7.55^{\star * \star}\right)\end{array}$ & $\begin{array}{c}-0.0000 \\
0.92\end{array}$ & $\begin{array}{c}0.7037 \\
-\end{array}$ & $\begin{array}{c}26.12 \\
2.36\end{array}$ & $\begin{array}{l}0.0024 \\
0.0003\end{array}$ \\
\hline 3 & $r$ & $\begin{array}{c}0.01297 \\
\left(6.30^{\star * \star}\right)\end{array}$ & $\begin{array}{l}-0.23180 \\
\left(4.61^{\star * *}\right)\end{array}$ & $\begin{array}{l}0.40788 \\
\left(3.24^{\star *}\right)\end{array}$ & $\begin{array}{c}0.17661 \\
\left(6.88^{\star * \star}\right)\end{array}$ & - & $\begin{array}{c}0.6066 \\
-\end{array}$ & $\begin{array}{c}29.80 \\
2.05\end{array}$ & $\begin{array}{l}0.0044 \\
0.0011\end{array}$ \\
\hline 4 & $e$ & $\begin{array}{c}7.80854 \\
\left(65.95^{\star * \star}\right)\end{array}$ & $\begin{array}{l}13.05127 \\
\left(4.51^{\star * *}\right)\end{array}$ & $\begin{array}{c}-16.0404 \\
\left(2.22^{\star *}\right)\end{array}$ & $\begin{array}{c}-1.12602 \\
(0.76)\end{array}$ & $\begin{array}{l}- \\
-\end{array}$ & $\begin{array}{c}0.3318 \\
-\end{array}$ & $\begin{array}{l}9.60 \\
0.10\end{array}$ & $\begin{array}{l}0.2520 \\
3.6844\end{array}$ \\
\hline
\end{tabular}

Note: All equations were run using the OLS technique. The numbers in parentheses below the estimated coefficients indicate $t$-values; ${ }^{\star},{ }^{\star}$ and ${ }^{\star * *}$ indicate the significant at the $10 \%, 5 \%$ and $1 \%$ level, respectively. $R^{2}=$ coefficient of determination; $F=F$ - statistic; D.W. $=$ Durbin-Watson statistic; SER = standard error of the regression; $S S R=$ sum of squared residuals; Other symbols are defined in the text. Source: [13]. 
China's foreign exchange market has been in developing after 2010. In particular, the people's bank of China introduced a new foreign exchange market management system, allowing for greater exchange rate fluctuations and less restrictions on foreign exchange transactions in July 2014. Because of the greater change in exchange rates and foreign exchange reserves, the common role of foreign exchange reserves and exchange rate $(r+e)$ seems to be greater. This explains that the foreign exchange reserves and exchange rate sum $(r+e)$ as the explained variable is better than those of only one explained variable $r$ or $e$. As for the foreign exchange reserves are not sensitive to change in foreign prices $\left(p^{*}\right)$ and income $(y)$, it may be related to the fact that the sustaining growth of China's foreign exchange reserves in a long period of time is not related to the domestic and foreign economic growth. It is worth affirming that China's exchange rate and foreign exchange management system has been in constant reform and improvement, and will eventually form a highly developed exchange rate and foreign exchange market system [10].

\subsection{Exchange Rate Formation and Management Marketization}

The formation of exchange rates between $\mathrm{RMB}$ and foreign currency depends on both domestic foreign exchange market and international foreign exchange market. The exchange rate of the RMB to the United States Dollar, the Euro, the Hongkong Yuan, the British Pound, the Malaysian Ringgit, the Ruble, the Australian Dollar, the Canadian Dollar and the New Zealand Dollar are directly formed in domestic foreign exchange market (China foreign exchange trading center). The China's foreign exchange trading center releases the central parity of the RMB to these currencies every day and provides for the floating rate of spot market exchange rate.

The formation mechanism of the central parity of the RMB to the US Dollar is that, China foreign exchange trading center makes an inquiry to inter-bank foreign exchange market makers before the daily interbank foreign exchange market opening to make the market maker quotations as the calculation sample of the central parity rate for the RMB. After removing the highest and the lowest quotations, the remaining market maker quotations are weighted average, and the central parity of the RMB to the US Dollar is obtained. The weight was determined by the China foreign exchange trading center according to the trading volume and the quotation situation of the quoted party in the inter-bank foreign exchange market.

The central parity of the RMB to the Euro, the Hongkong Yuan and the Canadian Dollar are respectively determined by the China foreign exchange trading center according to the central parity of the RMB to the US Dollar in domestic foreign exchange market, and the exchange rate of the Euro, the Hongkong Yuan and the Canadian Dollar to the US Dollar at 9:00 am on that day respectively in international foreign exchange market. The central parity of the RMB to the Japanese Yen, the British Pound, the Australian Dollar, the New Zealand Dollar, the Malaysian Ringgit and the Russian Ruble, is respectively calculated by the 
China foreign exchange trading center according to the quoted average price of the corresponding currency of the direct trading market maker in the inter-bank foreign exchange market before the opening of the daily interbank foreign exchange market.

The trading price of RMB to the US Dollar may fluctuate within the range of $2 \%$ on the central parity of the RMB to the US Dollar released by the China foreign exchange trading center. The trading price of RMB to the Euro, the Hongkong Yuan, the British Pound, the Australian Dollar, and the New Zealand Dollar may fluctuate within a range of $3 \%$ on the central parity of the corresponding currency issued by the China foreign exchange trading center. The trading price of RMB to the Malaysian Ringgit and the Russian Ruble is within the range of $5 \%$ on the central parity of the corresponding currency issued by the China foreign exchange trading center [11].

The exchange rate of RMB to other currencies is made through cross calculation according to the exchange rate of RMB to the US Dollar in domestic foreign exchange market and the exchange rate of these currencies to the United States Dollar in the international foreign exchange market. Obviously, the formation of the RMB exchange rate has realized marketization operation. The country's management of exchange rate is mainly reflected on the fluctuation range of current exchange rate around the central parity. At present, domestic foreign exchange market is still relatively strictly managed by the Chinese government. However, China will gradually learn from the international advanced management experience to achieve the full integration of Chinese foreign exchange market with the international foreign exchange market.

\subsection{Co-Movement between Exchange Rate and Interest Rate}

As there is an intrinsic correlation between exchange rate and interest rate, so they jointly determine the macroeconomic equilibrium under the conditions of open economy. However, at this stage, China has not realized the interest rate marketization, which limits the marketization of exchange rate. Therefore, China should greatly promote the reform of the exchange rate and interest rate marketization operation in the future, both of which are indispensable. Otherwise, China's overall financial reform is difficult to achieve substantial progress.

For the reality of China, the key to the reform of interest rate marketization is how to promote the reform of domestic financial system, especially the cultivation and development of micro financial institutions, including banking financial institutions, non-bank financial institutions and financial intermediaries. Overall, China's financial institutions are mainly based on the banking financial institutions, and China has a large proportion of banks in the banking financial institutions, which led to the problem of low financial efficiency and financial repression. Therefore, it is urgent and necessary for China to cultivate and develop effective micro financial institutions. The most feasible way is to cultivate and develop private financial institutions and introduce foreign financial institutions, so as to promote the reform and innovation of the whole financial institutions.

The key point of another reform is to strengthen the construction of domestic 
financial market, including funds market and capital market. From the international perspective, the current financing system in the world includes two types of the bank-oriented financing system and market-oriented financing system. China's history and realistic situation determines that at least in the present stage, China should take the bank-oriented financing system as the main body. However at the same time, China should also give full play to the role of the capital market to make up for the lack of bank financing. In general, China's capital market has still a deep-seated problem of lack of competitiveness at the current stage. Therefore, how to significantly improve the efficiency of the capital market is the focus of future reform. China has not formed an effective capital market, as market system and market supervision have still many problems. However in terms of reality, it is difficult to solve many problems at least in the short term, which it is necessary to do long-term unremitting efforts [12].

\section{Concluding Remarks}

The empirical analysis suggests that the experience of China for the period from the first quarter, 2010 to the first quarter, 2017, provides a good example of the foreign exchange market in which the exchange market pressure of a country can be alleviated by combining change in one's reserves with change in one's exchange rates. The empirical analysis also suggests that the measure of exchange market pressure heavily depends on its composition between exchange rate and foreign exchange reserves. The evidence shows fairly well that most exchange market pressure in China is mainly absorbed through their joint adjustments in exchange rate and foreign reserves.

The policy implication from the above-mentioned conclusions is that, in order to efficiently alleviate the exchange market pressure of China, the authorities should properly adjust the foreign reserves of the state and the exchange rates of the RMB, simultaneously. However, the change in the RMB exchange rates has been always limited in a very narrow band since 1997, and the exchange market pressure of China is hard alleviated mainly by means of the change in foreign reserves. This has made a lot of negative impact on the economy and the policy of China. On the one hand, a managed floating exchange rate system has not been actually brought into effect in China since 1994. On the other hand, only by means of the change in foreign reserves to dissipate the exchange market pressure of China, it may restrict the choice of the policy instruments of the authorities. Furthermore, it is disadvantage to the openness of financial market and introducing capital convertibility for China.

Therefore, it is necessary to properly broaden the band of the RMB exchange rates under the precondition of keeping the relative stabilization of the foreign exchange market in China for the long haul. At present, one of the most important matters is to actualize the market-oriented reform of the RMB Exchange rate formation mechanism for China. That is to say that the RMB Exchange rates should be determined by the market power of the supply and the demand for the foreign exchange. This is the best choice of policies for China under current condition [13]. 


\section{Acknowledgements}

An earlier version of this paper was presented at the international conference on the $2^{\text {nd }}$ International Conference on Business Management and Electronic Information (BMEI 2012), and published in The Proceedings of the $2^{\text {nd }}$ International Conference on Business Management and Electronic Information (BMEI 2012, VOL.1, 60-63). The constructive comments of anonymous reviewers are thankfully acknowledged.

\section{References}

[1] Connolly, M. and Taylor, D. (1976) Testing the Monetary Approach to Devaluation in Developing Countries. Journal of Political Economy, 84, 849-859. https://doi.org/10.1086/260481

[2] Magee, S. (1976) The Empirical Evidence on the Monetary Approach to the Balance of Payments and Exchange Rates. American Economic Review, 66, 163-170.

[3] Girton, L. and Roper, D. (1977) A Monetary Model of Exchange Market Pressure Applied to the Postwar Canadian Experience. American Economic Review, 67, 537-548.

[4] Connolly, M. and Silveira, J.D.D. (1979) Exchange Market Pressure in Postwar Brazil: An Application of the Girton-Roper Monetary Model. American Economic Review, 69, 448-454.

[5] Burdekin, R.C.K. and Burkett, P. (1990) A Re-Examination of the Monetary Model of Exchange Market Pressure: Canada, 1963-1988. The Review of Economics and Statistics, 72, 677-681. https://doi.org/10.2307/2109609

[6] Modeste, N.C. (1981) Exchange Market Pressure during the 1970s in Argentina: An Application of the Girton-Roper Monetary Model. Journal of Money, Credit, and Banking, 13, 234-240.

[7] Kim, I. (1985) Exchange Market Pressure in Korea: An Application of the GirtonRoper Monetary Model. Journal of Money, Credit, and Banking, 17, 258-263. https://doi.org/10.2307/1992339

[8] Ning, Y., Wang, Y.M. and Su, C.W. (2017) How Did China's Foreign Exchange Reform Affect the Efficiency of Foreign Exchange Market? Physica A, 483, 219-226. https://doi.org/10.1016/j.physa.2017.04.150

[9] Johnson, H. (1972) The Monetary Approach to Balance-of-Payments Theory. Journal of Financial and Quantitative, 7, 1555-1571. https://doi.org/10.2307/2329935

[10] Seghezzaa, E., Morellib, P. and Pittalugac, G.B. (2017) Reserve Accumulation and Exchange Rate Policy in China: The Authoritarian Elite's Aim of Political Survival. European Journal of Political Economy, 46, 40-51. https://doi.org/10.1016/j.ejpoleco.2016.10.011

[11] State Administration of Foreign Exchange (2017) The Notice of the People's Bank of China on the Management of the Inter-Bank Foreign Exchange Market Transaction and the Bank Listing Exchange Rate (July 2014). (In Chinese) http://www.safe.gov.cn/

[12] Dou, X.S. (2010) The Analysis of RMB Exchange Rate Stability under the Background of Post-Financial Crisis. Pacific journal, 18, 53-59. (In Chinese)

[13] Dou, X.S. and Chi, S.Z. (2012) Exchange Market Pressure in China: An Application of the Girton-Roper Monetary Model. The Proceedings of the 2 nd International Conference on Business Management and Electronic Information, 1, 60-63. 
Submit or recommend next manuscript to SCIRP and we will provide best service for you:

Accepting pre-submission inquiries through Email, Facebook, LinkedIn, Twitter, etc. A wide selection of journals (inclusive of 9 subjects, more than 200 journals)

Providing 24-hour high-quality service

User-friendly online submission system

Fair and swift peer-review system

Efficient typesetting and proofreading procedure

Display of the result of downloads and visits, as well as the number of cited articles Maximum dissemination of your research work

Submit your manuscript at: http://papersubmission.scirp.org/

Or contact tel@scirp.org 